\title{
Singing and Speaking in Louis MacNeice's The Burning Perch
}

\section{Dominique Delmaire}

\section{(2) OpenEdition \\ 1 Journals}

\section{Electronic version}

URL: http://journals.openedition.org/etudesirlandaises/5352

DOI: 10.4000/etudesirlandaises.5352

ISSN: 2259-8863

\section{Publisher}

Presses universitaires de Caen

\section{Printed version}

Date of publication: 29 November 2017

Number of pages: 105-121

ISBN: 978-2-7535-7388-8

ISSN: 0183-973X

\section{Electronic reference}

Dominique Delmaire, "Singing and Speaking in Louis MacNeice's The Burning Perch », Études irlandaises [Online], 42-2 | 2017, Online since 29 November 2017, connection on 15 September 2019. URL : http://journals.openedition.org/etudesirlandaises/5352; DOI : 10.4000/etudesirlandaises.5352 


\title{
Singing and Speaking in Louis MacNeice's The Burning Perch
}

\author{
Dominique Delmaire \\ Université Lumière-Lyon 2
}

\begin{abstract}
The Burning Perch has come to epitomize the much-praised "lyrical return" of a poet who is known to have had an ear for fine rhythmic nuances. In addition, a large number of poems in the collection are in "dolnik" (or near-dolnik) verse, which is the meter of balladry, nursery rhymes, and much of the popular poetry commonly associated with song. In this context, it becomes especially interesting to study the poetic voice in relation to the intrinsic dialectic between singing and speaking at work in the book. This essay examines how, through the perpetual reassertion of this voice against any rhythmic environment liable to smother it, a compromise is achieved which sacrifices neither "the swing of the primitive form" (MacNeice) nor the poet's desire for articulate meaning.
\end{abstract}

Keywords: Louis MacNeice, voice, singing, speaking; dolnik

\section{Résumé}

De l'avis général, The Burning Perch incarne désormais le "retour du lyrisme " chez un poète dont, par ailleurs, la sensibilité aux plus subtiles nuances rythmiques est bien connue. En outre, le mètre utilisé dans un grand nombre de poèmes du recueil est grosso modo le "dolnik ", c'est-à-dire celui qui prévaut dans les ballades et comptines, ainsi que dans une bonne partie de la poésie populaire indissociable de la chanson. Dans un tel contexte, il devient particulièrement intéressant d'étudier la voix poétique dans son rapport à la dialectique de la parole et du chant intrinsèquement à l'ouvre dans le livre. On essaiera de montrer comment, grâce à l'acte de résistance renouvelé de cette voix contre toute emprise rythmique susceptible de l'étouffer, un compromis est atteint par lequel ne sont sacrifiés ni le " "swing" de la forme primitive " (MacNeice) ni le désir du poète d'exprimer un sens intelligible.

Mots clés: Louis MacNeice, voix, chant, parole, dolnik

The "lyrical impulse", which, according to Louis MacNeice himself, had returned with Visitations (1957), was only further confirmed in the subsequent volumes, Solstices (1961) and The Burning Perch (1963) ${ }^{1}$. In the latter, the issue

1. Louis MacNeice, Selected Literary Criticism, Alan Heuser (ed.), London, Faber \& Faber, 1987 (henceforth SLC), p. 211. See also Peter McDonald, Louis MacNeice: The Poet in His Contexts, Oxford Clarendon Press, 1991, p. 177; Peter McDonald, "Louis MacNeice: Irony and Responsibility", Matthew Campbell (ed.), The Cambridge 
of the voice becomes prominent, notably in "Budgie", the keystone poem of a collection that owes it its title and in which the speaking bird, whose voice is "a small I Am", stands in part for the poet struggling with self-expression and communication. The volume's shifting voices - "running on from one thing to the next" in "Soap Suds", or "wry, civilized, ironic" ${ }^{3 "}$ in "Memoranda to Horace" reflect the "many different selves" of an "incorrigibly plural" ${ }^{4}$ " poet. For all these fluctuations, The Burning Perch may still be regarded as an "attempt at articulating a personal voice", a way both "to introduce myself to me" - as MacNeice had put it earlier ${ }^{6}$ - and to address, and often dialogue with, various real, historical or imagined persons: Mary Wimbush in "To Mary" and "Coda", the "ladies and gentlemen" of "The Suicide", the milkman and the airman of "The Pale Panther", the various trees of "Tree Party", and many other addressees, such as fellow poet Horace (to whom MacNeice declares, "I would pitch on the offchance/My voice to reach you $\left.{ }^{7 ”}\right)$, not to mention, of course, the attentive reader implied in every poem. Thus welcomed and heard by another, the lyrical subject can, as Jean Michel Maulpoix has shown, recognize himself and fully exist ${ }^{8}$.

This lyric voice may sing or speak. "In the days that were early the music came easy", recalls MacNeice, whose finely tuned ear could distinguish the similarly "easy music" of Blake from the "subtle music" of Yeats's "little mechanical songs" - as Yeats himself called them - or the "very intricate music" of T. S. Eliot's "The Waste Land", owing to "a lifetime's acuteness of hearing ${ }^{10 "}$ which began with early exposure to "the delicate pattern of nursery rhymes" sung by his mother and went on all the way to his reprise of children's rhymes and songs in poems such as "Children's Games"1".

Singing, however, is not, for MacNeice, the be all and end all of poetry. Nursery rhymes themselves are at the same time subtly musical (the very opposite of the "far cruder music" which many adults demand once they have stopped

Companion to Contemporary Irish Poetry, Cambridge, CUP, 2003, p. 63; Robyn Marsack, The Cave of Making: The Poetry of Louis MacNeice, London, OUP, 1985, p. 105.

2. The Burning Perch, London, Faber \& Faber, 2001 [1963] (henceforth BP), p. 37.

3. Peter McDonald, "Louis MacNeice: The Burning Perch", Neil Roberts (ed.), A Companion to Twentieth-Century Poetry, Oxford, Clarendon Press, 1991, p. 493; William T. McKinnon, Apollo's Blended Death: A Study of the Poetry of Louis MacNeice, London, OUP, 1971, p. 192.

4. Louis MacNeice, The Poetry of W. B. Yeats, London, Faber \& Faber, 2008 [1941] (henceforth PWBY), p. 146;

"Snow", Collected Poems, London, Faber \& Faber, 1979 (henceforth CP), p. 30.

5. Peter McDonald, Louis MacNeice: The Poet in His Contexts, p. 194.

6. Modern Poetry: A Personal Essay, London, OUP, 1969 [1938] (henceforth MP), p. 64.

7. BP, p. 39.

8. See "La quatrième personne du singulier. Esquisse de portrait du sujet lyrique moderne", Dominique Rabaté (dir.), Figures du sujet lyrique, Paris, PUF, 2005 [1996], p. 155.

9. Autumn Journal, XVIII, 1. 1-4, CP 136; PWBY, p. 141; MP, p. 166.

10. Peter McDonald, "Louis MacNeice: The Burning Perch", p. 493.

11. MacNeice, $M P$, p. 36; BP, p. 27. 
appreciating them) and made up of the "running trochees and dactyls of ordinary English speech"; likewise, the "simple notes" of "wellworn tunes" can, in "Off the Peg", gain "the power of speech" ${ }^{12}$ ". Overindulgence in music is, in MacNeice's view, actually often harmful. By dismissing "the pull and thrust of meaning" the poet runs the risk of compromising clarity for the sake of "the music of the verse", "sacrificing [...] thought to music and colour ${ }^{13}$ ". Certainly, as Mladen Dolar has pointed out, singing "brings the voice energetically to the forefront $[\ldots]$ at the expense of meaning ${ }^{14 "}$, a danger Socrates was already cautioning against in Plato's Phaedrus - a reference MacNeice seems to have had in mind when he comments on "the repetitive/Cicadas endors[ing] [Horaces's] sleep after lovemaking" in "Memoranda to Horace ${ }^{15}$ ". Just as Socrates and Phaedrus were at risk of being "lulled to sleep by the locusts' song because of [their] mental indolence ${ }^{16 "}$, the music of rhyme ("naturally suited to verse which imitates song rather than speech", as Derek Attridge notes ${ }^{17}$ ) may, in MacNeice's view, "[lull] the reader into a pleasant coma $^{18}$.

That is why the poet should not just sing, but also speak, "employing all kinds of devices to atone for the lack of the one great asset, which the speakers had and he has not, the tones of the spoken voice ${ }^{19}$ ". MacNeice's "own preference is for poetry which is musical" but which is also characterized by "(a) system and (b) significance ${ }^{20 "}$. Thought, meaning, communication are all-important. As Peter MacDonald points out about the poet's late work, his "mastery of form" and "extraordinary technical control of phrase and timing" contribute to the reader's impression of "straightforward speaking - to what MacNeice in the 1930s would have called 'communication' $[\ldots]^{21}$ ".

MacNeice's attraction to both music and speech warrants a study of the poetic voice in The Burning Perch in relation to these two poles. In addition, because MacNeice himself advised the "poetry reviewer" to discuss such "points as the relation between a poet's sentence structure and verse pattern, $[\ldots]$ or his variation of stresses", and because of his own admission that "many of the poems here have been trying to get out of the 'iambic' groove which we were all born into ${ }^{22 \text { ", }}$

12. $M P$, p. 36 (italics mine), $41 ; B P$, p. 46.

13. SLC, p. 32 (the author's italics); $M P$, p. $174,56$.

14. A Voice and Nothing More, Cambridge, MA (USA), MIT Press, 2006, p. 30.

15. BP, p. 40.

16. Plato, Phaedrus, 259a, Harold N. Fowler (ed. and trans.), Plato in Twelve Volumes, Vol. 9, Cambridge, MA, Harvard University Press; London, William Heinemann, 1925. Ibid., 259a.

17. Moving Words: Forms of English Poetry, Oxford, OUP, 2013, p. 56. [Henceforth MW.]

18. $M P$, p. 131.

19. Ibid., p. 139.

20. Ibid., p. 134.

21. Peter McDonald, "Louis MacNeice: Irony and Responsibility", p. 65.

22. SLC, p. 169, 248. 
one feels emboldened to give this study a markedly rhythmic spin. Accordingly, I shall argue that, as the poetic voice rises to prominence by setting itself off against its metrical environment, it takes on very different characteristics depending on whether this environment is strictly accentual-syllabic, as in some of the pieces in the collection, or more akin to the "dolnik" verse form (a term which will require some elucidation) that colors much of The Burning Perch.

Four poems in the volume are in regular tetrameter ${ }^{23}$ : "Château Jackson", "The Grey Ones", "Birthright", and "Greyness is All". "Château Jackson" begins like this:

Where is the Jack that built the house

That housed the folk that tilled the field

That filled the bags that brimmed the mill

That ground the flour that browned the bread

That fed the serfs that scrubbed the floors

The unrelenting mechanical repetitiveness which it shares with the other three places it in the category of "ictosyllabic meter, where there is both a primary regulation (of beats) and a secondary one (of the measure)" - that is, of "the number of syllables between any two ictus within the line ${ }^{24 "}$ - without the positional flexibility of beats allowed by more complex meters; this creates what MacNeice calls "the monotonous regularity of well-timed stresses ${ }^{25}$ ", well suited to suggest the inexorability of the fate that man has brought upon himself in the form of quasi-certain nuclear annihilation in "Greyness is All" ("Until the final switch is thrown/To black out all the worlds of men ${ }^{26 ")}$ and other poems of the collection.

More importantly, as Groves notes, "the inflexibility of that pattern seems to crush all resistance (and thus lifelikeness and interest) out of the language-material", thus, in Xavier Kalck's words, "dispossessing the poet of his voice, as if the device of repetition itself took the lead ${ }^{27 "}$ ". These poems exemplify that "sheer hypnotic force" of which, according to MacNeice, the early twentieth century had become suspicious "on the ground that [it] saves thinking or excuses the lack of thought ${ }^{28}$ ". Neil Corcoran goes further: in his view, "[r]epetition is the realisa-

23. Julian Gitzen ("Louis MacNeice: The Last Decade”, Twentieth Century Literature, Vol. 14, No. 3, October 1968 , p. 140) counts twenty, but quite possibly because he includes the loose tetrameter verse that technically belong to the dolnik, as will be shown later.

24. Peter L. Groves, "Meter", Erik Martiny (ed.), A Companion to Poetic Genre, Hoboken (N.J.), Wiley-Blackwell, 2012, p. 40, 36.

25. $M P$, p. 142.

26. BP, p. 32.

27. Groves, op. cit., p. 40; Kalck, Muted Strings. Louis MacNeice's The Burning Perch, Paris, PUF-CNED, 2015, p. 122.

28. $P W B Y$, p. 145. 
tion of death ${ }^{29}$ ", or as Joseph Attié puts it, "mortiferous", because it "can endlessly repeat itself without any change to the subject ${ }^{30}$ ", thus precluding any manifestation of the latter in the text, be it through thinking, speaking or singing. In truth, only disjunction, that is, non-coincidence (in Adolphe Haberer's terms, "le décalage qui fait jouer différence et répétition ${ }^{31}$ "), permits the appearance of the subject. This is the difference between repetition and rhythm. As Attié cogently remarks,

[Le rythme] suppose la répétition, mais la répétition n'engage pas toujours un rythme. [...] L'efficace du rythme revient à centrer le sujet pour, à chaque fois, le décentrer hors du même, vers un ouvert, impossible à circonscrire à l'avance $^{32}$.

Now MacNeice does avail himself of this possibility in the aforementioned poems. One example can be taken from "Greyness is All” (1. 9-11):

If only some black demon would

o B -o- B ô B o $\quad$ B

Infuse our small grey souls we could

$\begin{array}{llllllll}\text { o } & \mathrm{B} & \mathrm{O} & \mathrm{B} & \mathrm{O} & \mathrm{B} & \mathrm{O} & \mathrm{B}\end{array}$

At least attempt to break the wire

$\begin{array}{lllllll}\text { o } & \mathrm{B} & \text { o B } & \text { o } & \text { B } & \text { o } & B^{33}\end{array}$

Here emphasis on "black demon" or "small grey souls" is achieved by means of consecutive stresses, and it will have special significance, as I shall demonstrate later on. Technically, the first of these two perfectly allowed variations (specifically: "(on)ly some black de(mon)", scanned as “-o- B ô B") is called, in Derek Attridge's terminology, a "rising inversion"; it changes nothing to the expected alternation of beats and offbeats, except that it momentarily speeds up the move-

29. "The Same Again? Repetition and Refrain in Louis MacNeice", Cambridge Quarterly, Vol. 38, No. 3 (2009), p. 217.

30. Mallarmé le livre. Etude psychanalytique, Nice, éditions du losange, 2007, p. 374 (my translation).

31. Louis MacNeice, 1907-1963 : l'homme et la poésie, 2 vol., Bordeaux, Presses Universitaires, 1986, p. 699.

32. Op. cit., p. 374.

33. The scansion model used in this study is the one developed by Derek Attridge in The Rhythms of English Poetry (London, Longman, 1982) and Poetic Rhythm. An Introduction (Cambridge, CUP, 1995), and Thomas Carper and Derek Attridge in Meter and Meaning: An Introduction to Rhythm in Poetry (New York and London, Routledge, 2003). This system, which relies on beat-offbeat metrics, distinguishes between stresses and beats. These may coincide - as when emphasized beats (B) alternate with unemphasized offbeats (o) - or may not - in which case beats can be unemphasized (b) and offbeats emphasized (O). Offbeats can also be "implied" (ô), that is, not realized by a syllable and thus equivalent to a pause between two syllables that are not separated by punctuation or a syntactic boundary. (When these latter are divided by a punctuation mark, the implied offbeat is called a "virtual offbeat" and is symbolized by "[o]".) Finally, offbeats can be double (-o-) or triple $(\sim \mathrm{O} \sim)$, that is, associated with two or three syllables. I am thankful to Pr. Derek Attridge for his precious feedback on the scansions proposed in this study. 
ment of the line, by compressing the two syllables of the double offbeat into the space of one, and then slows it down, by creating a short break on the following silent offbeat. What makes it quite special here is that it is the only such variation in the entire poem. Similarly, "Birthright" features its only falling inversion - i.e. the reverse (B ô B -o-) of a rising inversion and "a highly disruptive presence ${ }^{34 \text { " }}$ in tetrameter verse - on "jaw dropped and I" in the penultimate line, "My jaw dropped and I gaped from drouth", thus materializing through the slight pause between "the disruptive pair of emphasized beats"35" ("jaw" and "dropped"), the actual "jaw-dropping" of the speaker's "gap[ing]" mouth. MacNeice himself comments on a similar phenomenon, which he calls "an equivocation of rhythm itself significant", in the famous Thomas Nashe poem, "Adieu, Farewell Earth's Bliss", citing the following line:

Strength stoops unto the grave,

O B ôB - o - B

about which he declares that "the first three syllables of the lines are beautifully varied with great emotional effect ${ }^{36 "}$, thus showing how fully aware he is of the emotional charge released by such a rhythmic figure.

Another rising inversion, similar to that of "Greyness is All", is to be found in "The Grey Ones" (1. 19). The only one of its kind and therefore all the more significant, it occurs almost exactly halfway through the poem, at a crucial moment when the speaker recounts his confrontation of the Grey ones' Gorgonian stare:

Every such what and where betwixt

$\mathrm{B}-\mathrm{O}-\mathrm{B} \quad \mathrm{O} \quad \mathrm{B} \quad \mathrm{O}$ B

Your fact and fancy stays transfixed

$\begin{array}{lllllllllllll} & \mathrm{B} & \mathrm{O} & \mathrm{B} & \mathrm{O} & \mathrm{B} & \mathrm{O} & \mathrm{B}\end{array}$

By that one unremitting stare

- o - B ôB o B o B

Which cancels what you never were,

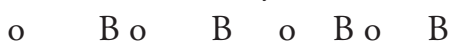

34. Attridge, Poetic Rhythm, p. 119.

35. Carper and Attridge, op. cit., p. 83.

36. $M P$, p. 121. 
This is what Joanny Moulin terms "la rencontre définitive du Réel", which "dis-

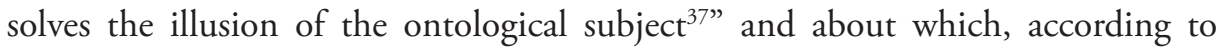
Lacan, nothing can be said - except maybe in a heavy stammer: /one un-/.

Although these variations remain within the bounds of strict accentual-syllabic meter - in the sense that they do not upset either the beat count or the syllable count - one can see how much of the subject's emotions or affects they carry. Yet MacNeice often goes much further, bypassing the very principles of strict octosyllabic verse altogether. This happens - again only once - in "Château Jackson".

There is, in this frighteningly regular piece, a major irregularity at the end of the first section, where the line

That built the house that Jack built?

o B o B o B ô B

conspicuously misses an offbeat between "Jack" and "built". Indeed, for it to remain acceptable within the poem's metrical design, it would have had to be, for instance:

That built the house that this Jack built?

o B o B $\quad-$ o- B ô B

which is a line with the right number of syllables and the now familiar rising inversion at the end. But in MacNeice's poem, an implied offbeat occurs between two emphasized beats without any prior or subsequent compensation in the form of a double offbeat (as is the case in a rising or falling inversion), causing a major dislocation in the meter. Of course, the original nursery rhyme need not abide by such rules since it is in dolnik verse, which, as we shall see, includes offbeats of variable sizes, from triple to implied, and most commonly double, as in "This is the dog that worried the cat" or "This is the cow with the crumpled horn".

This rhythmic disruption both dramatizes the enigma of Jack's identity and whereabouts, and points up the reappearance of the speaking subject who had seemingly been erased by the self-perpetuating word machine that is the poem. In particular, the offbeat occurs in a silence, and is hence associated with "exactly what cannot be said", which is Jacques-Alain Miller's definition of the "aphonic" voice of unutterable desire ${ }^{38}$, as it manifests itself in "Greyness is All", a poem in "almost always iambic tetrameters ${ }^{39}$ " except for one slightly, yet fundamentally, different line (1. 12):

At least attempt to break the wire

$\begin{array}{llllllll}\text { o } & \mathrm{B} & \text { o } & \mathrm{B} & \mathrm{o} & \mathrm{B} & \mathrm{O} & \mathrm{B}\end{array}$

37. Louis MacNeice: The Burning Perch, Neuilly-sur-Seine, Atlande, 2016, p. 136 (with my translation).

38. "Jacques Lacan et la voix", De la Voix. Quarto, Vol. 54 (1994), p. 51, 48 (my translation).

39. Kalck, op. cit., p. 122 (my emphasis). 
That bounds the Gadarene hens' desire.
o
B
o B -o-
B o B

Again, the "free" double offbeat in "Gadarene hens" is not technically allowed in strict syllabotonic verse. It makes the line extra-metrical, allowing the couplet's rhythm to literally act out its statement, that is, attempt "to break the wire/That bounds the Gadarene hens' desire" - in other words, let the poet's own desire (possibly the "black demon" discussed earlier) break free from the constraints of the chosen form. The "Gadarene hens' desire" might ultimately be construed as the Hyde part of the poet's psyche, "the self which, as a poet, he would wish to suppress and subordinate", and which now resurfaces and "complements and corrects Jekyll, sometimes indeed by sabotage ${ }^{40}$ ".

Interestingly, the two transgressive rhythmic patterns discussed so far - the uncompensated-for implied offbeat of "Château Jackson" and the free double offbeat of "Greyness is All" - occurring each only once, not only manifest the way in which the poet's voice pries open a rigid metrical form; they also point to an altogether different model which, though largely under-discussed, is very old and common, both in popular and art poetry: the "dolnik".

The dolnik (from the Russian original) is an "intermediary verse form in several European literatures; it occupies a transitional position between syllabotonic and accentual verse ${ }^{41}$ ". It has been "the staple of popular song and verse [...] since at least the beginning of the thirteenth century ${ }^{42}$ " and widely used by many poets throughout the centuries, as early as the Middle Ages ("The majority of the thirteenth- to fifteenth-century lyrics printed in the Norton Anthology use dolnik verse $^{43}$ "), and abundantly so in the last two centuries - especially in the Romantic and Victorian eras - including by Coleridge, Blake, Swinburne, Tennyson, Browning, Kipling, Walter de la Mare, Yeats, Frost, Auden, Langston Hughes, John Betjeman, Sophie Hannah, etc ${ }^{44}$. "Dolnik verse proper has a number of definite properties: it is always in four-beat measures (including the possibility of the fourth beat's being virtual), is always rhymed, and always varies in the number of inter-beat unstressed syllables ${ }^{45}$ ". In addition, as Attridge notes about the nursery rhyme "Tom, Tom, the piper's son" (scanned B[o]BoBoB), "the absence of unstressed syllables between many of the beats encourages the emergence of a powerful, regular rhythm, propelling the reader away from the modulations of the

\footnotetext{
40. MacNeice, $M P$, p. 77.

41. Marina Tarlinskaja, "Beyond 'Loose Lamb': The Form and Themes of the English 'Dolnik", Poetics Today, Vol. 16, n 3, "Metrics Today" I (Autumn 1995), p. 497.

42. Derek Attridge, "The Rhythms of the English Dolnik", 2016, yet to be published, p. 5.

43. Attridge, $M W$, p. 155.

44. See $M W$, chpt. 7.

45. Attridge, "The Rhythms of the English Dolnik", p. 10.
} 
spoken language and towards something more like a chant ${ }^{46 "}$ - something we will need to keep in mind.

Among earlier MacNeice poems in dolnik are "Bagpipe Music ${ }^{47}$ ", scanned as follows by Attridge ${ }^{48}$ :

Annie MacDougall went to milk, caught her foot in the heather,

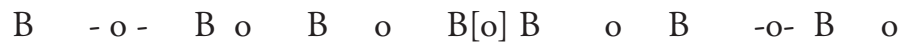

Woke to hear a dance record playing of Old Vienna.

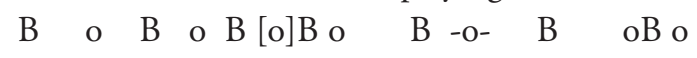

and "London Rain" ${ }^{49 "}$ :

The rain of London pimples

$$
\text { o } \quad \text { B }
$$

The ebony street with white

$$
\text { o B - o - B o } \quad \text { B } \quad[o B]
$$

And the neon-lamps of London

$$
\text { - o- Bo B o B o }
$$

Stain the canals of night

$$
\mathrm{B}-\mathrm{o}-\mathrm{B} \text { o } \quad \mathrm{B} \quad[\mathrm{oB}]
$$

It is to be noted that in the latter example, the fourth beat is not sounded, even though it remains quite perceptible. This is perfectly legitimate and happens regularly in the even lines of a ballad in "common meter", for instance.

The springy lilt that characterizes these poems is also present in a great number of pieces in The Burning Perch, in particular - and significantly - in the opening and closing poems, "To Mary":

Forgive what I give you. Though nightmare and cinders,

$\begin{array}{llll}o \mathrm{~B} & -\mathrm{o}-\mathrm{B} & -\mathrm{o}-\mathrm{B} & -\mathrm{o}-\mathrm{B} \text { o }\end{array}$

The one can be trodden, the other ridden,

o B - o- B - o- B o B o

and "Coda": 
So much for the past; in the present

$\mathrm{B} \sim \mathrm{O} \sim \mathrm{B}[\mathrm{o}] \mathrm{B}$ o $\mathrm{B}$ o

There are moments caught between heart-beats

$\mathrm{B} \quad \mathrm{O} \quad \mathrm{B} \quad \mathrm{O} \quad \mathrm{B} \quad-\mathrm{o}-\mathrm{B} \quad \mathrm{O}$

When maybe we know each other better.

o $\quad \mathrm{B}-\mathrm{o}-\mathrm{B} \quad \mathrm{O} \quad \mathrm{B}$ o $\mathrm{B}$ o

as well as in the central one, "Budgie":

The budgerigar is baby blue,

o $\quad \mathrm{B}-\mathrm{O}-\mathrm{B}$ o $\mathrm{B}$ o $\mathrm{B}$

Its mirror is rimmed with baby pink,

o $\mathrm{B} \quad-\mathrm{O}-\mathrm{B} \quad \mathrm{O} \quad \mathrm{B}$ o B

Its cage is a stage, its perks are props,

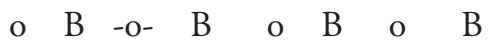

Its eyes black pins in a cushionette,

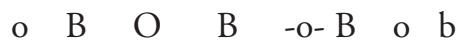

Its tail a needle on a missing disc,

$\mathrm{o} \quad \mathrm{B}$ o $\mathrm{B} \sim \mathrm{O} \sim \mathrm{B}$ o $\mathrm{B}$

In fact, the whole of The Burning Perch is placed, as it were, under the sign of the dolnik, if the acceptation of the term can be loosened enough to allow for enjambment and lack of rhyme, and thus include, in addition to the poems already mentioned: "Pet Shop", "After the Crash", "Spring Cleaning", "Another Cold May", "New Jerusalem", "Charon", "The Introduction", "Children's Games", "Tree Party”, "Sports Page”, "This is the Life”, "Goodbye to London", and "Coda".

The dominant effect created by the dolnik rhythm in most of these pieces is one of inherent briskness and bounciness which usually triumphs over whatever other impression may be generated by the poem. In "Pet Shop", for instance, the reader experiences a feeling of surfeit due to excess of description which is only compounded by a slow-moving syntax hindered, as Xavier Kalck points out, by the breaks in each line ${ }^{50}$ :

Cold blood or warm, crawling or fluttering

$\mathrm{O} \quad \mathrm{B} \quad \mathrm{O} \quad \mathrm{B}[\mathrm{o}] \mathrm{B} \quad-\mathrm{o}-\mathrm{B}-\mathrm{o}-$

50. Ibid., p. 51. 
Bric-a-brac, all are here to be bought.

B - o - B o B - o - B

Noisy or silent, python or myna,

B - o - Bo B - o-B o

Fish with long silk trains like dowagers,

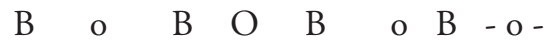

Monkeys lost to thought.

$\begin{array}{llllll}\mathrm{B} & \mathrm{O} & \mathrm{B} & \mathrm{O} & \mathrm{B}\end{array}$

In a small tank tiny enamelled

- o - B ô B ôB - o- Bo

In truth, however, these breaks or stalling points in the syntax do not matter so much in the end, as they are literally absorbed by the insistent rhythm. The first line, for example, features a very common dolnik configuration, found also in Hopkins's "Inversnaid":

This darksome burn, horseback brown,
o $\quad$ B $\quad \mathrm{o}$
$\mathrm{B}[\mathrm{o}] \mathrm{B} \quad \mathrm{o}$
B

in which the sudden rhythmic suspension resulting from the virtual offbeat ([o]) only adds to the impetus of the line and generates its characteristic dolnik lilt, which elsewhere is produced by "the varying number of syllables between the beats ${ }^{51}$ ". This is even more noticeable in line 5 :

In a small tank tiny enamelled

- o- B ô B ôB - o-Bo

where the two consecutive virtual offbeats are framed by double offbeats, creating an effect of systole/diastole which, coupled with the alliteration on "tank tiny", causes the line to spring up again - as did line 1 owing also to the assonance on "warm, crawl". In short, the brisk energy of the dolnik overcomes the stuffiness of the atmosphere. And when the pace temporarily breaks into a wooden trochaic rhythm in stanza four ("Rabbit, hamster, potto, puss"), it is only to pick up the dolnik momentum all the better again:

Something to hold on the lap and cuddle
B $\quad-0-B-0-B \quad 0 \quad$ B o

51. Attridge, "The Rhythms of the English Dolnik", p. 8. 
The same could be argued about the sprightly pace of "To Mary". Here, the energetic, overpowering rhythm, combined with the multiple run-ons, most appropriately conveys the speaker's unflinching resolve and headlong rush toward his "improbable" destination, literally overriding the bleakness and adversity depicted.

It is probably, however, in "Children's Games" that the reader can get the full measure of the dolnik's irresistible drive, boosted by multiple instances of syncopation due to missing beats and offbeats. This is magnified by the fact that the poem is a collage of nursery rhymes and children's counting-out and other games, popular sayings, etc. that often involve a collective voice. Peter Groves's comment on "Tom, Tom, the piper's son" - echoeing Derek Attridge's previously quoted remark - about the chant-like character of such verse, seems especially fitting at this stage:

The first thing we notice about this is its insistent rhythmicality: simple meter co-opts the strong isochrony we find in counting and listing $[\ldots]$ and tends to distort the performance of the verse away from naturalistic speech, towards chanting. It thus represents a communal verseform, easily chanted in groups (e.g. of children, Shakespearean witches, protestors, and so on $)^{52}$.

Here is a tentative scansion of the beginning of "Children's Games":

Touch me not forget me not, touch me forget me,

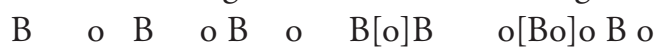

Throw salt over your shoulder when you walk under a ladder,

$$
\text { o } \quad \text { B ôB-o- } \quad \text { B o[Bo] B o } \quad \text { B o B o B o }
$$

Fly away, Peter, they are waiting in the Vatican,

$\mathrm{B}$ o $\mathrm{B}[\mathrm{o}] \mathrm{Bo}[\mathrm{Bo}] \mathrm{B}$ o $\quad \mathrm{B}$ o $\quad \mathrm{b} \quad \mathrm{o} \quad \mathrm{B}$ - o -

Come back, Paul, to your Macedonian runaround.
B o
$\mathrm{B}[\mathrm{oBoB}]-\mathrm{O}-$
$\mathrm{B}$ o B o
B - o -

Hop scotch and somersault ring a ring of raspberries.

$\begin{array}{llllllllllllll}\text { B ô } & \text { B } & \text { o } & \text { B } & \text { o } & \text { B } & {[o]} & \text { B } & \text { o } & \text { B } & \text { o } & \text { B } & \text { o } & \text { b }\end{array}$

Who shall we send to fetch her away? Touch wood and turn again.
B
- o - B o B
B - o - B [o] B ô
B $\quad$ o $\quad$ B

52. Ibid., p. 36. 
I'm the king of the barbican, come down you dirty charlatan.
B o
B - o - B o b o
B o
$\mathrm{B}$ o $\mathrm{B}$ o b

When you see a magpie put salt upon her tail.

B $\quad$ o $\quad$ B o

While the poem is a hodgepodge of very disparate cultural elements - which, in Xavier Kalck's view, "cause the song to break down ${ }^{53}$ " - it is arguably held together as a powerfully chanted piece by the sheer thrust and "almost incantatory swing ${ }^{54}$ " of the dolnik rhythm. It acquires the same kind of ritualized and quasi-magical efficacy as a rhyme like "Here we go round the prickly pear" in T. S. Eliot's "The Hollow Men":

Here we go round the prickly pear

$$
\mathrm{B} \quad-\mathrm{O}-\mathrm{B} \quad \mathrm{O} \quad \mathrm{B} \text { o B }
$$

Prickly pear prickly pear

$$
\mathrm{B} \quad \mathrm{o} \text { B }[\mathrm{o}] \mathrm{B} \quad \mathrm{o} \mathrm{B}
$$

I would argue that the chanting in "Children's Games" puts on an equal footing, and digests in the same manner, the unexpected juxtaposition of the game of hopscotch and the (rewritten) nursery rhyme of "Ring a ring of roses" on one hand, and the unspeakable horror of the suggested lynching scene on the other, in a kind of communal ritualizing of that horror.

While this return to an oral tradition of collective chanting and singing may be motivated by MacNeice's lifelong enthusiasm for popular verse forms that are "historically [...] associated with song 55 ", it does not quite seem to allow the poet's own voice to be heard, in the way it is heard through, for instance, the rhythmic transgressions he permits himself in strict tetrameter, as those are not only fully allowed by the dolnik, but are what defines the form. So the question for him now is how to reclaim a more personal voice within a verse form which seems to induce a kind of trance-like, musical Nietzschean disappearance of the subject $^{56}$. This is a fine line indeed, which MacNeice encapsulates in the following terms: "while it is an asset to have an idiom, an idiom is only valuable as a diffe-

\section{Ibid., p. 117.}

54. Attridge, $M W$, p. 159.

55. Ibid., p. 152.

56. See Amittai F. Aviram, Telling Rhythm. Body and Meaning in Poetry, Ann Arbor, University of Michigan Press, 1994, p. 214: "this moment at which the subject begins to lose itself is also the moment at which music comes in to fill the gap. Music is left when the subject falls away". 
rentiation of what is communal ${ }^{57}$. Expressing his own voice is going to require, in particular, leaving behing the overpowering "rhythmicality of song ${ }^{58}$ ".

One way of doing this is by dislocating the form, in a manner which is reminiscent of what he did with tetrameter verse. In "Budgie", for example, the dolnik is pushed to its limit and begins to crack at the seams, as it were, with the normally very rare triple offbeat slackening the rhythm, making it bulge into a succession of paeons $[\mathrm{B} \sim \mathrm{O} \sim]$, a foot used in Greek comedy. This is abundantly displayed in those scenes where the parrot is absorbed in the contemplation of himself, and it is, of course, part of the satirical force of the piece:

The small blue universe, so Let me attitudinise,
o B
$\mathrm{O} \mathrm{Bo}$
$-\mathrm{o}-\mathrm{B} \sim \mathrm{o}-\mathrm{B}-\mathrm{o}-$

Let me attitudinise, let me attitudinise,

$$
\mathrm{B} \sim \mathrm{o}-\mathrm{B}-\mathrm{o}-\mathrm{B} \sim \mathrm{o} \sim \mathrm{B}-\mathrm{o}-
$$

For all the world is a stage is a cage

$$
\text { o } \quad \mathrm{B} \text { o } \quad \mathrm{B}-\mathrm{o}-\mathrm{B}-\mathrm{o}-\mathrm{B}
$$

A hermitage $\mathrm{a}$ fashion show $\mathrm{a}$ crèche an auditorium

$$
\mathrm{o} B \sim \mathrm{O} \sim \mathrm{B} \sim \mathrm{O} \sim \mathrm{B} \sim \mathrm{O} \sim \mathrm{B} \mathrm{o}
$$

Or possibly a space ship. Earth, can you hear me?

$$
\mathrm{o} \quad \mathrm{B} \sim \mathrm{O} \sim \mathrm{B} \quad \mathrm{O} \quad \mathrm{B}-\mathrm{o}-\mathrm{B} \quad \mathrm{O}
$$

Blue for Budgie calling Me for Mirror:

$\mathrm{B} \quad \mathrm{O} B \sim \mathrm{O} \sim \mathrm{B}$ o B o

Budgie, can you hear me? The long tail oscillates,

$$
\mathrm{B} \sim \mathrm{o} \sim \mathrm{B}-\mathrm{o}-\mathrm{B} \mathrm{O} \text { B - o - }
$$

What it also shows, to an admittedly extreme degree, is that, by speaking, the subject - here caricatured as a budgie with which the poet partially and self-derisively identifies - can upset the fragile balance of the dolnik rhythm and make it stop singing.

Another way is to use formal features that belong more naturally with duple meters - such as enjambment and mid-line syntactic breaks - and tend to lessen the dolnik's vitality. That is the case in "To Mary": 
Forgive what I give you. Though nightmare and cinders,
o B
$-\mathrm{o}-\mathrm{B}$
- o-
B $\quad-0-B$ o

The one can be trodden, the other ridden,

o B - o- B - o- B o B o

We must use what transport we can. Both crunching

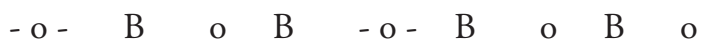

Path and bucking dream can take me

$\begin{array}{llllllllllllllllll}\mathrm{B} & \mathrm{O} & \mathrm{B} & \mathrm{O} & \mathrm{B} & \mathrm{O} & \mathrm{B} & \mathrm{O}\end{array}$

or in "The Grey Ones", where run-ons occur in between quatrains, a most usual place in dolnik verse, in which syntax normally meshes with lineation. In "After the Crash", they actually prevent what could have been the fourth silent beat in an instance of three-beat dolnik, and propel the reading onward to the next line instead:

When he came to he knew

Time must have passed because

The asphalt was high with hemlock

Through which he crawled to his crash

Helmet and found it no more

Than his wrinkled hand what it was.

In all these examples the absence of rhyme also contributes to steering the rhythm away from the dolnik, as rhyme normally clinches the periodic unity of each quatrain. "Another Cold May" is an extreme case of enjambments and midline syntactic breaks:

With heads like chessmen, | bishop or queen,

The tulips tug at their roots and mourn

In inaudible frequencies, $\mid$ the move

Is the wind's, | not theirs; | fender to fender

The cars will never emerge, | not even

Should their owners emerge to claim them, | the move

Is time's, | not theirs; | elbow to elbow

[...]

Here "the rhythmicality of song" seems to have been truly lost and replaced by the "unpredictable variety of speech" ${ }^{59}$. 
To break with the "easy music" he had praised in these anapaestic lines from Autumn Joumal, "In the days that were early the music came easy/On cradle and coffin, in the corn and the barn ${ }^{60}$, the poet may also choose a duple rhythm, which "will dominate the language less than a triple rhythm" - normally "furthest from spoken English (and nearest to song) ${ }^{61}$ ".

In poems like "Réchauffé" or "The Introduction", his hesitation between the dolnik and a more accentual-syllabic kind of verse is certainly perceptible. In "Réchauffe", many lines have a dolnik swing, switching freely from iambs to anapaests:

And yet who knows what sudden thrust

$\begin{array}{llllllll}\mathrm{o} & \mathrm{B} & \mathrm{O} & \mathrm{B} & \mathrm{O} & \mathrm{B} & \mathrm{o} & \mathrm{B}\end{array}$

In the guts, what gripe in the mind, might burst

- o- B o B - o - B $\quad 0 \quad$ B

The dams on the breast of the mad?

o B - o- B - o- B

Yet the final stress clash in the first lines of each stanza (e.g. "of the dark tombs" in "The food on the walls of the dark tombs", or "of the sun's rays" in "The hands on the ends of the sun's rays", both scanned: "-o- B ô B") is undolniklike ${ }^{62}$. In fact, this very same rising inversion, found in the first and last lines of "The Introduction" (respectively "in a grave glade" and "in a green grave"), calls to mind a famous line by Andrew Marvell from "Thought in a Garden", "To a green thought in a green shade", in which it is duplicated. This rhythmic figure, used only in the strictest of accentual-syllabic verse (Marvell's iambic tetrameter is a case in point), thus gestures toward an altogether different metrical context, one which is associated with meditation and self-expression, and which conflicts with the prevailing dolnik trend upheld in "The Introduction" by means of the nonsensical "crawly crawly", that is, at the expense of, precisely, thought and meaning. In "Réchauffé", the rising inversion in the first line of each stanza definitely clashes with the plain triple rhythm of the last line, which is an apocopated replica of the first one (e.g. "The hands on the ends of the sun" [1. 14] echoes "The hands on the ends of the sun's rays" (1. 8]). The "uncanny ring" of this truncated line, suggesting that "the possibility of catastrophe lies only a small variation on normality away ${ }^{63 "}$, results precisely from the tension between two metrical systems.

60. First lines of section 18 (CP, p. 136).

61. Attridge, $M W$, p. 124.

62. See Tarlinskaja, op. cit., p. 501, 510.

63. Kalck, op. cit., p. 106; McDonald, The Poet in His Contexts, p. 198. 
While the last line has a self-perpetuating ternary motion that makes it oracular, non-human and possibly menacing, the first one has more of the reassuring characteristics of spoken language.

Those are some of the ways in which the poet's voice attempts to reconquer some ground against the almost irresistible dolnik. Did Louis MacNeice also have in mind this tug-of-war between singing (or chanting) and speaking when he described the poems in The Burning Perch as "two-way affairs"? And was he speaking also for himself when he declared about T. S. Eliot, "I admired Eliot's technique - the blend of conversation and incantation ${ }^{64 "}$ ? The key to understanding the place of the poet's voice in The Burning Perch might be the notion of compromise, which MacNeice appears to have shared with Yeats and Auden regarding the right distance to adopt vis-à-vis popular poetry and song. As he perceptively noted in terms that could apply to him,

in both Yeats and Auden there is a compromise; they do not go more than halfway towards the genuine ballad or street-song; the poet achieves some of the simplicity or the directness or the swing of the primitive form but he does not pretend away (as the early Yeats tried to) his own sophisticated self ${ }^{65}$. 